\title{
Chemical structures, rheological and physical properties of biopolyols prepared via solvothermal liquefaction of Enteromorpha and Zostera marina biomass
}

\author{
Paulina Kosmela $\cdot$ Kamila Gosz $\cdot$ Paweł Kazimierski • Aleksander Hejna • \\ Józef Tadeusz Haponiuk $\cdot$ Lukasz Piszczyk (i)
}

Received: 25 February 2019/ Accepted: 27 May 2019/Published online: 30 May 2019

(C) The Author(s) 2019

\begin{abstract}
In this work, liquefied biomass from the Baltic Sea was used for the preparation of rigid polyurethane (PUR) foams. The biomass contained 10 wt $\%$ of Enteromorpha macroalgae and $90 \mathrm{wt} \%$ of Zostera marina seagrass characterized by a high content of cellulose. The influence of time, temperature and the type of solvent on the efficiency of the liquefaction process and properties of biopolyols was determined. Obtained materials were analyzed in terms of chemical structure, rheological properties, thermal stability and basic physical and mechanical
\end{abstract}

P. Kosmela · K. Gosz · A. Hejna · J. T. Haponiuk

Ł. Piszczyk ( $\bowtie)$

Department of Polymer Technology, Chemical Faculty,

Gdansk University of Technology, G. Narutowicza Str.

11/12, 80-233 Gdańsk, Poland

e-mail: lukpiszc@pg.gda.pl

P. Kosmela

e-mail: paulina.kosmela@pg.edu.pl

K. Gosz

e-mail: kamila.gosz@pg.edu.pl

A. Hejna

e-mail: aleksander.hejna@pg.gda.pl

J. T. Haponiuk

e-mail: jozhapon@pg.gda.pl

P. Kazimierski

Institute of Fluid Flow Machinery, Fiszera Str. 14,

80-231 Gdańsk, Poland

e-mail: pkazimierski@imp.gda.pl properties. It was found that optimal parameters for liquefaction of used biomass were: temperature of $150{ }^{\circ} \mathrm{C}$, reaction time of $6 \mathrm{~h}$ and a solvent mixture containing glycerol and poly(ethylene glycol) in ratio of 50:50 (biopolyol 50G50P_150). Under these conditions, $78 \mathrm{wt} \%$ of biomass was liquefied and resulting biopolyol was characterized by a hydroxyl number of $650 \mathrm{mg} \mathrm{KOH} / \mathrm{g}$. Depending on the used solvent mixture and the liquefaction temperature, biopolyols showed the character of Newtonian or non-Newtonian liquids. Rigid PUR foams were obtained by substitution of petrochemical polyol with 10, 20 and $30 \mathrm{wt} \%$ of biopolyol. It was found that the addition of biopolyol to foams' formulations did not cause significant changes in their chemical structure, while mechanical strength and thermal stability were enhanced. The presented study confirms that biomass from the Baltic Sea can be used for the synthesis of biopolyols and rigid polyurethane foams.

Keywords Bio-based polyols $\cdot$ Algae $\cdot$ Biomass liquefaction $\cdot$ Rigid polyurethane foam

\section{Introduction}

The annual, global consumption of plastics is around 140 million tonnes, which consumes around 150 million tonnes of fossil fuels. Such a large production generates huge amounts of waste, which is very 
harmful for the environment (Suriyamongkol et al. 2007). Due to the consumption of fossil fuels and the rise of environmental pollution, many scientists are directing their research towards "green" plastics (Stevens 2003). One of the most important renewable resources used in the plastics industry is biomass from wood (Zimmermann et al. 2014; Bi et al. 2018; Guo et al. 2018) and crop plants (Karimia et al. 2017; Hejna et al. 2018a, b; Hemamalini and Dev 2018): corn (Nouraddini et al. 2018), soy (Dhaliwala et al. 2018), potatoes (Bergel et al. 2018), cassava (Luchese et al. 2017) and other edible plants (Ubeyitogullari and Ciftci 2016; Halal et al. 2015). Due to the controversial use of food resources, there is a need to find sustainable non-food renewable sources. Interesting alternative that can be used in plastics industry is biomass from the aquatic environment (including algae). Biomass of algae contains large amounts of carbohydrates and small amounts of lignin, which makes algae an excellent candidate for the synthesis of bioplastics (Kuruppalil 2011; Pathak et al. 2014). The use of algae for bioplastics can be carried out directly or indirectly. Direct methods include mixing polymers with algae biomass, while indirect methods use algae biomass to obtain a component for the synthesis of bioplastics, e.g. algae oil. In addition, the biomass of algae is a direct source of biopolymers, such as agar, carrageenan and alginate.

The literature extensively describes the preparation of polyurethane (PUR) materials using alginate (Oh et al. 2011; Yun et al. 2007; Yuvarani et al. 2015). Interesting research was conducted by Chen and others (Chen et al. 2016). They prepared fire-resistant polyurethane foams containing an alginate-montmorillonite coating (AM) in the form of an aerogel. Polyurethane foams together with the AM coating with a thickness of $0.2-1.5 \mathrm{~mm}$ were frozen in a bath with ethanol/liquid nitrogen (about $-114^{\circ} \mathrm{C}$ ), and later dried in a lyophilizer at a pressure of $5 \mathrm{~Pa}$. The obtained AM coating was characterized by smaller pore diameters compared to polyurethane foams. It also showed strong interaction with the polyurethane, because during the lyophilization process, the AM suspension got into the foam structure. The flammability tests showed that foams with AM coatings had higher LOI (32-60) and TTI (3-10 s) values compared to unmodified foams $(\mathrm{LOI}=17$, TTI $=1)$. Authors determined that total heat of combustion was the lowest for the sample with $1.5 \mathrm{~mm}$ layer of aerogel comprised of $5 \mathrm{~g}$ of alginate and $10 \mathrm{~g}$ of montmorillonite. They claimed that such phenomenon was associated with barrier effect of applied modifications.

Another idea for the use of algae biomass is the synthesis of biopolyols for the manufacturing of polyurethane foams. Algae oil shows similar properties to other vegetable oils, which for many years have been a substrates for the synthesis of biopolyols. In the literature, one can find reports on the use of algae oil for the synthesis of biopolyols, which are then used to obtain rigid PUR foams. Pawar et al. (2016) described the synthesis of biopolyol based on algae from the Chlorella species. The synthesis consisted of an oxidation reaction using hydrogen peroxide and acetic acid, followed by the opening of the oxirane ring using lactic acid or ethylene glycol. Modified rigid polyurethane foams showed properties similar to those of foams based on conventional, petrochemical polyols.

Kim et al. (2015) proposed a method for obtaining biopolyols and polyurethane foams. They performed solvothermal liquefaction of microorganisms in polyethylene glycol and glycerol in the presence of sulfuric acid as a catalyst. The authors pointed out that algae are a promising raw material for liquefaction because, unlike most types of biomass, they do not contain lignin, which impedes liquefaction. In addition, microalgae contain relatively high amount of free fatty acids, which can be easily converted into monoglycerides-monomers that can be used for the synthesis of polyurethanes. The article presents the influence of individual synthesis parameters, i.e. the ratio of poly(ethylene glycol) to glycerol, temperature and reaction time, as well as the biomass:solvents ratio and catalyst loading, on the properties of the biopolyols. The optimal reaction conditions were: PEG/ glycerol ratio $6 / 4$, reaction temperature $190{ }^{\circ} \mathrm{C}$, reaction time $60 \mathrm{~min}$, catalyst loading $5 \mathrm{wt} \%$ and $20 \mathrm{wt} \%$ of biomass. Under these conditions, a biopolyol with a hydroxyl number of $650 \mathrm{mg} \mathrm{KOH} / \mathrm{g}$, and acid number of $9 \mathrm{mg} \mathrm{KOH} / \mathrm{g}$ was obtained, while biomass conversion reached $88.5 \%$.

Interesting solution was proposed by Mayfield and Ruddick (Ruddick and Fishman 2015; Mayfield 2015), who producedthe world's first polyurethane surfboard using algae oil. Authors modified the algae oil and obtained reactive polyols, subsequently used for the synthesis of foamed polyurethanes. In cooperation with Arcitic Foam, they created a prototype of the surfboard core. The first reviews state that prepared 
boards are characterized by similar quality, as well as slightly higher flexibility compared to classic boards.

The presented study evaluated the potential use of the liquefaction of biomassfrom the Baltic Sea to obtain components used in manufacturing of rigid PUR foams. The influence of the reaction time (1-6 h), temperature $\left(120-180{ }^{\circ} \mathrm{C}\right)$ and the type of solvent (crude glycerol, poly(ethylene glycol)) on the process efficiency (biomass conversion), chemical structure (FTIR), hydroxyl value, water content and rheological properties was determined. In addition, selected biopolyol was used to prepare rigid PUR foams, whose basic properties were determined (processing parameters, compressive strength, thermal stability, cell size and chemical structure).

\section{Experimental}

\section{Materials}

Biomass used for the synthesis of biopolyols contained $10 \mathrm{wt} \%$ of Enteromorpha macroalgae and $90 \mathrm{wt} \%$ of Zostera marina seagrass and originated from the Baltic Sea (harvest date: June 2017). The characteristics of used biomass are presented in Table 1. Figure 1 shows a microscopic image of Zostera marina, which contain visible cellulose fibers. As a solvent for the liquefaction process, purified crude glycerol containing 99\% of glycerol ( $\mathrm{LOH}=1104$ $\mathrm{mg} \mathrm{KOH} / \mathrm{g}$, water content $<0.5 \%$ ) obtained from Bio-Chem Sp. $\mathrm{z}$ o.o. and poly(ethylene oxide) (PEG400) $\quad(\mathrm{LOH}=314 \mathrm{mg} \quad \mathrm{KOH} / \mathrm{g}$, water

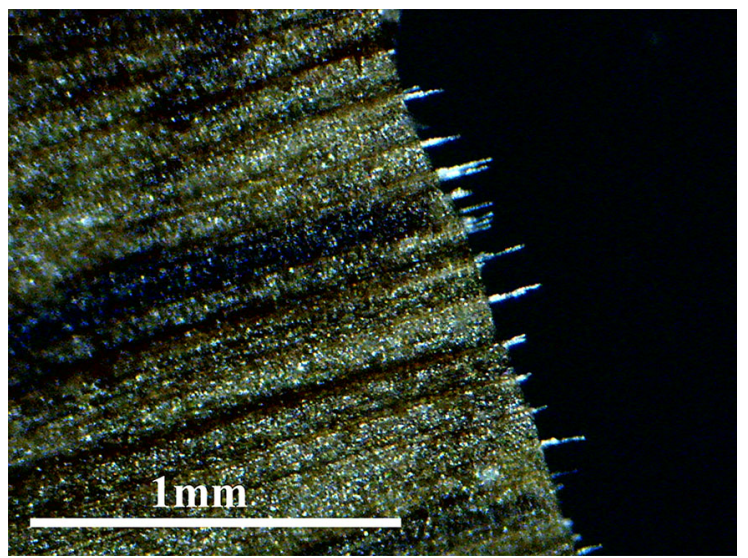

Fig. 1 Microscopic image of Zostera marina

content $<0.3 \%$ ) from POCH S.A. During the synthesis, sulfuric acid (VI) was applied as a catalyst and sodium hydroxide was used to neutralize biopolyols, both reagents derived from POCH S.A.

Rigid PUR foams were obtained using 50G50P_150 biopolyol and Rokopol ${ }^{\circledR}$ RF551 petrochemical polyol (polyoxyalkylene sorbitol) from PCC Group. The selected properties of polyols are shown in Table 2. The isocyanate component was a polymeric methylenediphenyl-4,4'-diisocyanate (pMDI) with a free NCO content of $31.5 \%$ from BASF. The following were used as catalysts: $33 \mathrm{wt} \%$ potassium acetate solution in ethylene glycol-PC CAT ${ }^{\circledR}$ TKA30 from Performance Chemicals, $75 \mathrm{wt} \%$ potassium octoate solution in diethylene glycol-Dabco K15, 33 wt\% solution of triethyl diamine in dipropylene glycolDabco33LV from Air Products and dibutyltin
Table 1 The chemical composition of biomass from the aquatic environment

\begin{tabular}{|c|c|c|c|}
\hline Biomass & Chemical composition & Dry weight (pbw) & Literature \\
\hline \multirow[t]{3}{*}{ Enteromorpha } & Polysaccharides & $<75$ & (Briand et al. 2005) \\
\hline & Sulphureous & $<20$ & \\
\hline & Proteins & $<12$ & \\
\hline \multirow[t]{9}{*}{ Zostera marina } & Carbohydrates & $<15$ & (Cabello-Pasini et al. 2004) \\
\hline & Proteins & $<15$ & \\
\hline & Ash & $<40$ & \\
\hline & Fiber & $<60$ & \\
\hline & Fiber composition & & (Davies et al. 2007) \\
\hline & Cellulose & 57 & \\
\hline & Hemicellulose & 28 & \\
\hline & Pectin & 10 & \\
\hline & Lignin & 5 & \\
\hline
\end{tabular}


Table 2 Selected properties of polyols used to obtain PUR foams

\begin{tabular}{lllll}
\hline Polyol & Hydroxyl number $\left(\mathrm{mg}_{\mathrm{KOH}} / \mathrm{g}\right)$ & Viscosity $(\mathrm{mPa} \mathrm{s})$ & Density $\left(\mathrm{g} / \mathrm{cm}^{3}\right)$ & Water content $(\%)$ \\
\hline 50G50P_150 & 650 & 2236 & 1.21 & 0.2 \\
Rokopol ${ }^{\circledR}$ RF551 & 440 & $3000-5000$ & 1.06 & 0.1 \\
\hline
\end{tabular}

dilaurate (DBTDL) from Sigma Aldrich. Tegostab B 8465 from Evonik Industries AG was a surfactant (SPC), and $n$-pentane from Lach-ner was used as a blowing agent. Trichloropropyl phosphate (TCCP) was also added as a flame retardant, which further reduced the viscosity of the polyol mixture from LANXESS Deutschland GmbH. Addition of $10 \mathrm{wt} \%$ TCCP for foam formulations was also aimed at increasing their flexibility and was the basis for further research on the development of flame retardants.

Preparation of biopolyols

Biopolyols were obtained in the process of liquefaction of marine biomass using crude glycerol and poly(ethylene glycol) as solvents, in accordance with the patent application (Piszczyk et al. 2017). Before the synthesis, water biomass was cleaned, dried, grounded (particle size 50-300 $\mu \mathrm{m}$ ) and further dried for $24 \mathrm{~h}$ at $100{ }^{\circ} \mathrm{C}$. The solvents were dried using molecular sieves type 4A from POCH S.A. The synthesis of biopolyols included the reaction of solvolysis, i.e. the reaction between a solvent containing hydroxyl groups and biomass. The reaction was carried out in a glass reactor equipped with a mechanical stirrer. A suitable solvent and water biomass in a ratio of 10/1 were placed in the reactor. The compositions of biopolyols are presented in Table 3.

Table 3 Compositions of biopolyols obtained in the work
The whole system was mixed and heated to $50{ }^{\circ} \mathrm{C}$, after which $3 \mathrm{wt} \%$ of the catalyst was added. Next, reaction mixture was heated up to desired temperature of 120,150 or $180{ }^{\circ} \mathrm{C}$. The type of catalyst and temperature range were selected basing on literature data and previous work (Kosmela et al. 2017a, b). The study investigated the influence of temperature, type of solvent and reaction time on the properties of obtained biopolyols. During the liquefaction, a sample was taken every hour (for $6 \mathrm{~h}$ ) to analyze its properties and determine the progress of the reaction. Liquefaction process was carried out for $8 \mathrm{~h}$, but it was noted that over $6 \mathrm{~h}$ no further changes of hydroxyl value or biomass conversion were observed. Therefore, we included only results for reaction times up to $6 \mathrm{~h}$. Time $0 \mathrm{~h}$ was determined as a time in which reaction mixture reached desired temperature of reaction $-120,150$ or $180{ }^{\circ} \mathrm{C}$. Therefore, reaction could proceed to some extent before reaching reaction temperature. Then it was cooled down and the $\mathrm{pH}$ was measured. All biopolyols obtained were characterized by $\mathrm{pH} \sim 1.5$. For neutralization, an appropriate amount of $\mathrm{NaOH}$ was added and heated to $110{ }^{\circ} \mathrm{C}$ under reduced pressure to remove volatile, low molecular weight products, mainly water. All synthesis were repeated 3 times. Figure 2 presents the proposed course of the reaction depending on the solvents used.

\begin{tabular}{|c|c|c|c|c|}
\hline \multirow[t]{2}{*}{ Biopolyol symbol } & \multicolumn{4}{|c|}{ Raw materials (pbw) } \\
\hline & Biomass & Catalyst & PEG400 & Crude glycerol \\
\hline $100 \mathrm{G}$ & 10 & 3 & 0 & 100 \\
\hline 75G25P & 10 & 3 & 25 & 75 \\
\hline $50 G 50 P$ & 10 & 3 & 50 & 50 \\
\hline 25G75P & 10 & 3 & 75 & 25 \\
\hline $100 \mathrm{P}$ & 10 & 3 & 100 & 0 \\
\hline
\end{tabular}


Fig. 2 Proposed course of the main reaction occurring as a result of liquefaction of biomass: a waste glycerol, b PEG400, c glycerol/ PEG400 mixture

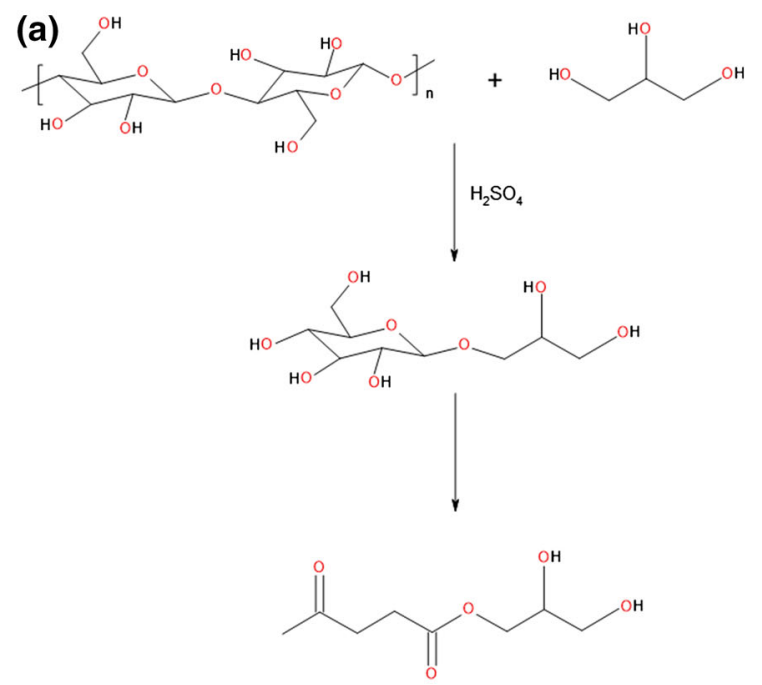

(b)

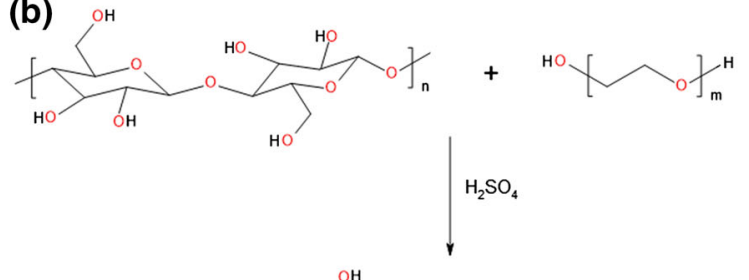

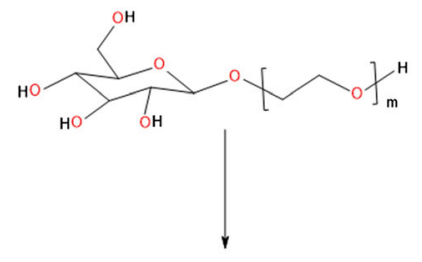<smiles>CC(=O)CCC(=O)OCCO[14CH3]</smiles>

(c)<smiles>COCCOCC(O)COC1OC(CO)C(O)C(O)C1O</smiles>

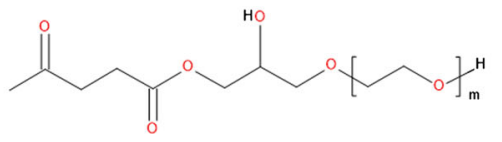


Preparation of rigid polyurethane foams

Rigid PUR foams were obtained using the one-step method from a two-component system. The isocyanate index $\left(\mathrm{I}_{\mathrm{ISO}}\right)$ was selected based on literature reports on rigid polyurethane foams (Modesti and Lorenzetti 2001) and was 200. Component A was a polyol mixture consisting of Rokopol ${ }^{\circledR}$ RF551 polyol or/and biopolyol 50G50P_150, catalysts, surfactant, flame retardant and blowing agent. Component B was an isocyanate. Foam formulations are presented in Table 4. Both components were mixed in a polypropylene cup with a mechanical agitator at a speed of $2000 \mathrm{rpm}$, poured into an open mold and heated for $24 \mathrm{~h}$ at $60^{\circ} \mathrm{C}$.

\section{Characterization of biopolyols}

The liquefaction extent was evaluated on the basis of the residue percent. Product $(1 \mathrm{~g})$ of the liquefaction was diluted (more than 10 times) by methanol, stirred with a magnetic stirrer for $4 \mathrm{~h}$ and then filtrated through the filter paper in vacuum. Solid residue was washed with methanol and then dried in the oven at $100{ }^{\circ} \mathrm{C}$ to a constant weight. Biomass conversion percent was calculated according to formula (1):

$B C=100-\frac{m}{m_{0}} \times 100 \%$

Table 4 The composition of reaction mixtures

\begin{tabular}{|c|c|c|c|c|}
\hline \multirow[b]{4}{*}{ Rokopol RF55 } & \multicolumn{4}{|c|}{ Foam symbol } \\
\hline & $\mathrm{P}_{0 \%}$ & $\mathrm{P}_{10 \%}$ & $\mathrm{P}_{20 \%}$ & $\mathrm{P}_{30 \%}$ \\
\hline & \multicolumn{4}{|c|}{ Raw materials (pbw) } \\
\hline & 100 & 90 & 80 & 70 \\
\hline Biopoliol 50G50P_150 & 0 & 10 & 20 & 30 \\
\hline $\mathrm{AC}$ & 0.5 & 0.5 & 0.5 & 0.5 \\
\hline Dabco $15 \mathrm{~K}$ & 0.5 & 0.5 & 0.5 & 0.5 \\
\hline Dabco 33LV & 0.5 & 0.5 & 0.5 & 0.5 \\
\hline DBTDL & 0.5 & 0.5 & 0.5 & 0.5 \\
\hline TEGOSLAB B 8465 & 6 & 6 & 6 & 6 \\
\hline n-pentan & 12.5 & 12.5 & 12.5 & 12.5 \\
\hline TCCP & 10 & 10 & 10 & 10 \\
\hline pMDI & 203.6 & 214.7 & 225.8 & 237.0 \\
\hline
\end{tabular}

where $m$ is the weight of residual biomass and $m_{o}$ is the initial weight of biomass.

Hydroxyl number of bio-based polyol was determined according to PN-93/C-89,052/03. Samples of $0.5 \mathrm{~g}$ were placed in $250 \mathrm{~cm}^{3}$ Erlenmeyer flasks with acetylating mixture. Next, it was heated for $30 \mathrm{~min}$, then $1 \mathrm{ml}$ of pyridine and $50 \mathrm{ml}$ of distilled water were added. Finally, resulting mixture was titrated using $0.5 \mathrm{M} \mathrm{KOH}$ solution in presence of phenolphthalein until the color of mixture changed to pink. Hydroxyl values were determined according to formula (2):

$H V=\frac{56,1 \cdot\left(V_{K O H}^{2}-V_{K O H}^{1}\right) \cdot C_{K O H}}{m}$

where $\mathrm{C}_{\mathrm{KOH}}$-concentration of $\mathrm{KOH}$, $\mathrm{V}_{\mathrm{KOH}}^{1}$ and $\mathrm{V}_{\mathrm{KOH}}^{2}$-volume of $\mathrm{KOH}$ used to titration of analyzed sample and blind test, $\mathrm{m}$-mass of sample.

FT-IR spectrophotometric analysis was performed in order to determine the structure of the bio-based polyol and rigid polyurethane foams. The analysis was performed at a resolution of $4 \mathrm{~cm}^{-1}$ using a Nicolet 8700 apparatus (Thermo Electron Corporation) equipped with a snap-Gold State II which allows for making measurements in the reflection configuration mode.

Viscosity values of prepared polyols were determined using R/S Portable rheometer. Temperature of the analysis was $25{ }^{\circ} \mathrm{C}$ and shear rate varied from 1 to $100 \mathrm{~s}^{-1}$. Obtained results were analyzed with Rheo 3000 computer software.

Water content of obtained biopolyols was analyzed using Karl-Fischer titration. Samples were diluted and titrated with Fischer reagent. Measurements of biopolyols density were performed using pycnometer at $25{ }^{\circ} \mathrm{C}$. Values of $\mathrm{pH}$ were measured with VOLTCRAFT pH-100 ATC $\mathrm{pH}$ meter at $25^{\circ} \mathrm{C}$.

All measurements were repeated 3 times.

Characterization of rigid polyurethane foams

The following process parameters were observed and characterized: start time (time elapsed from the start of the process until the start of volume expansion); rise time (time elapsed from the start of volume expansion until the foam reaches its maximum height); and tack free time (time elapsed from the moment the foam reaches its maximum height until the surface of the foam stops being tacky to the touch). 
The soluble (sol) fraction of each sample was determined by Soxhlet extraction, using xylene as a solvent. Around $1.5 \mathrm{~g}$ of sample was put inside a cellulose thimble and submitted to an extraction process for $24 \mathrm{~h}$. After extraction, the samples were dried for $24 \mathrm{~h}$ at $80{ }^{\circ} \mathrm{C}$ to remove the solvent and their weight was measured. The sol fraction was determined as the ratio of the difference between weight of the sample before extraction $\left(\mathrm{W}_{1}\right)$ and weight of the sample after extraction $\left(\mathrm{W}_{2}\right)$, relative to the weight of the sample before extraction $\left(\mathrm{W}_{1}\right)$, according to Eq. (3):

$X=\frac{W_{1}-W_{2}}{W_{1}} \cdot 100 \%$

The apparent density of polyurethanes samples was calculated in accordance to PN-EN ISO 845: 2000, as the ratio of the sample weight to the sample volume. The volume of the samples having a cubic shape was measured with a slide caliper having an accuracy of $0.1 \mathrm{~mm}$. The samples were weighed using an electronic analytical balance with an accuracy of $0.1 \mathrm{mg}$.

The compression strength of the PUR-PIR samples was estimated in accordance to PN-EN ISO 604:2006. The samples of cubic shape and dimensions of $50 \times 50 \times 50 \mathrm{~mm}^{3}$ were measured with a slide caliper with an accuracy of $0.1 \mathrm{~mm}$. The compression test was performed on a Zwick/Roell tensile tester at a constant speed of $10 \mathrm{~mm} / \mathrm{min}$ to $40 \%$ deformation.

Dynamic mechanical analysis was performer using DMAQ800 TA Instruments apparatus. Samples were analyzed in compression mode with a frequency of $1 \mathrm{~Hz}$. Measurements were performed for the temperature range from 35 to $270{ }^{\circ} \mathrm{C}$ with heating rate $4{ }^{\circ} \mathrm{C} /$ min. Samples were cylindrical-shaped with dimensions of $6 \times 18 \mathrm{~mm}$.

All measurements were repeated 3 times.

\section{Results and discussion}

\section{Characterization of biopolyols}

Figure 3 shows changes in hydroxyl number and degree of biomass conversion during liquefaction reaction with different solvents. As the reaction time increases up to $6 \mathrm{~h}$, drop of the hydroxyl number and an increase in the biomass conversion in all cases were observed. Further elongation of the reaction time did not result in significant changes of these properties. The simultaneous decrease of the hydroxyl number and the increase of biomass conversion indicates higher extent of conversion (Yao et al. 1995). During the liquefaction process, hydrolysis and alcoholysis reactions may occur (Yamada et al. 2001). The use of excess of solvent that condenses may result in generation of oligomers and polymers (e.g., polyglycerol from glycerol) and water (Hejna et al. 2018a, b). Water can break down a long chain of biomass molecules, generating free hydroxyl groups, which are responsible for the instantaneous increase of hydroxyl number. The reduction of hydroxyl number with progress of liquefaction is probably caused by the oxidation and dehydration of glycerol or the depolymerization of biomass components (Yao et al. 1995). The liquefaction carried out at $180{ }^{\circ} \mathrm{C}$ caused a distinct decrease of hydroxyl value during the process for each sample. Biopolyols obtained at this temperature (for samples containing up to $75 \%$ of glycerol) showed high viscosity, which adversely affects their processing properties. Lowering of process' temperature to $120{ }^{\circ} \mathrm{C}$ resulted in the minimal extent of the liquefaction reaction, which can be deduced from almost constant values of the hydroxyl number during the process, as well as from the heterogeneous form of obtained product. The liquefaction of biomass at $150{ }^{\circ} \mathrm{C}$ for all samples resulted in gradual decrease of the hydroxyl number over time, and the obtained products were homogeneous. Determination of biomass conversion efficiency indicates its dependence on both the process temperature and its duration. Biomass conversion increases with rise of temperature and reaction time. For samples containing only glycerol (for all temperatures) it increases gradually for $6 \mathrm{~h}$. A larger amount of poly(ethylene glycol) results in stabilization of the biomass conversion after about $3 \mathrm{~h}$. This suggests that the introduction of a second solvent may shorten the required time of liquefaction, which was also described in other work (Jo et al. 2015). Interesting results were obtained for the $100 \mathrm{G}$ sample, because it can be seen that for temperature of $180{ }^{\circ} \mathrm{C}$, the hydroxyl number is significantly reduced, and the biomass conversion does not increase rapidly. It suggests occurrence of a glycerol condensation reaction, along with the liquefaction of biomass. 
Fig. 3 Influence of time and temperature of the liquefaction reaction on the change of the hydroxyl number and biomass conversion depending on the solvents used
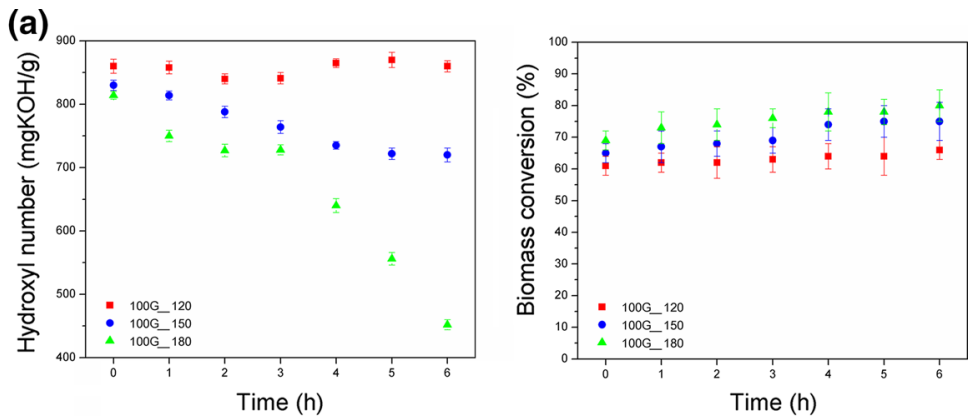

(b)
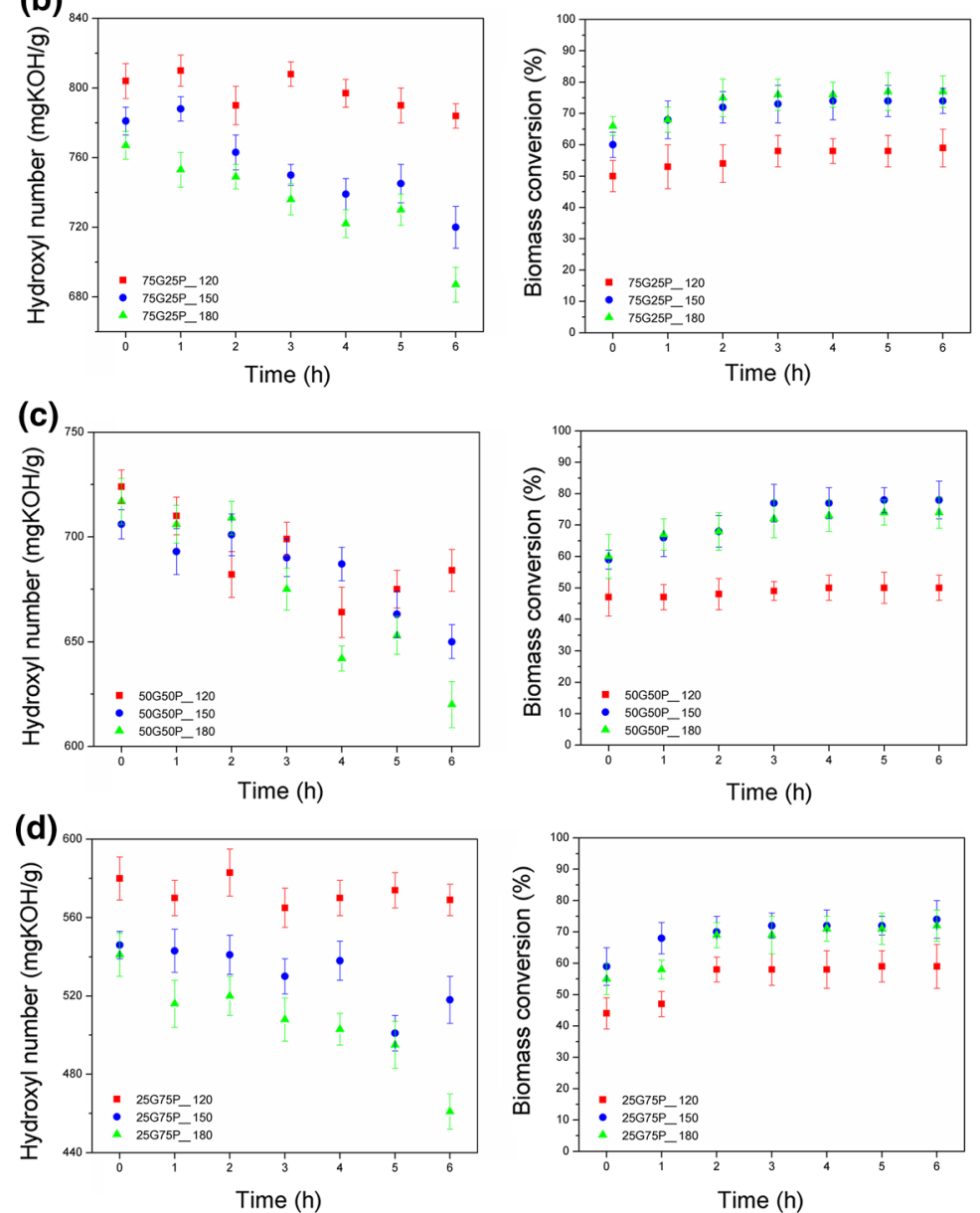

(e)
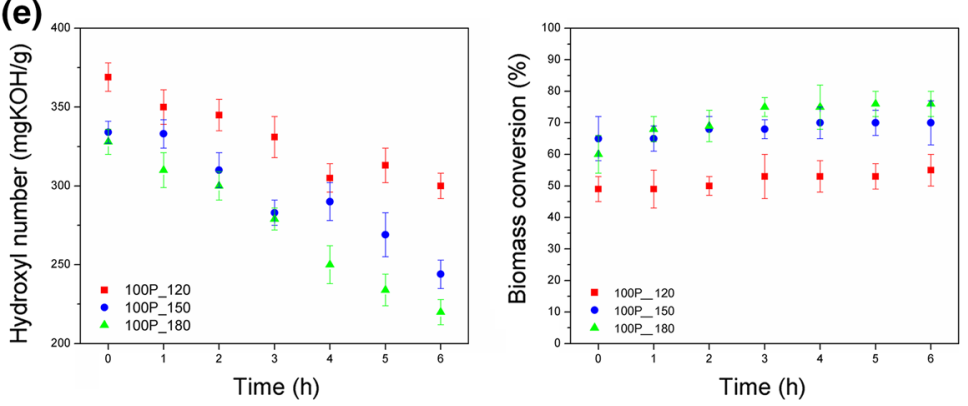

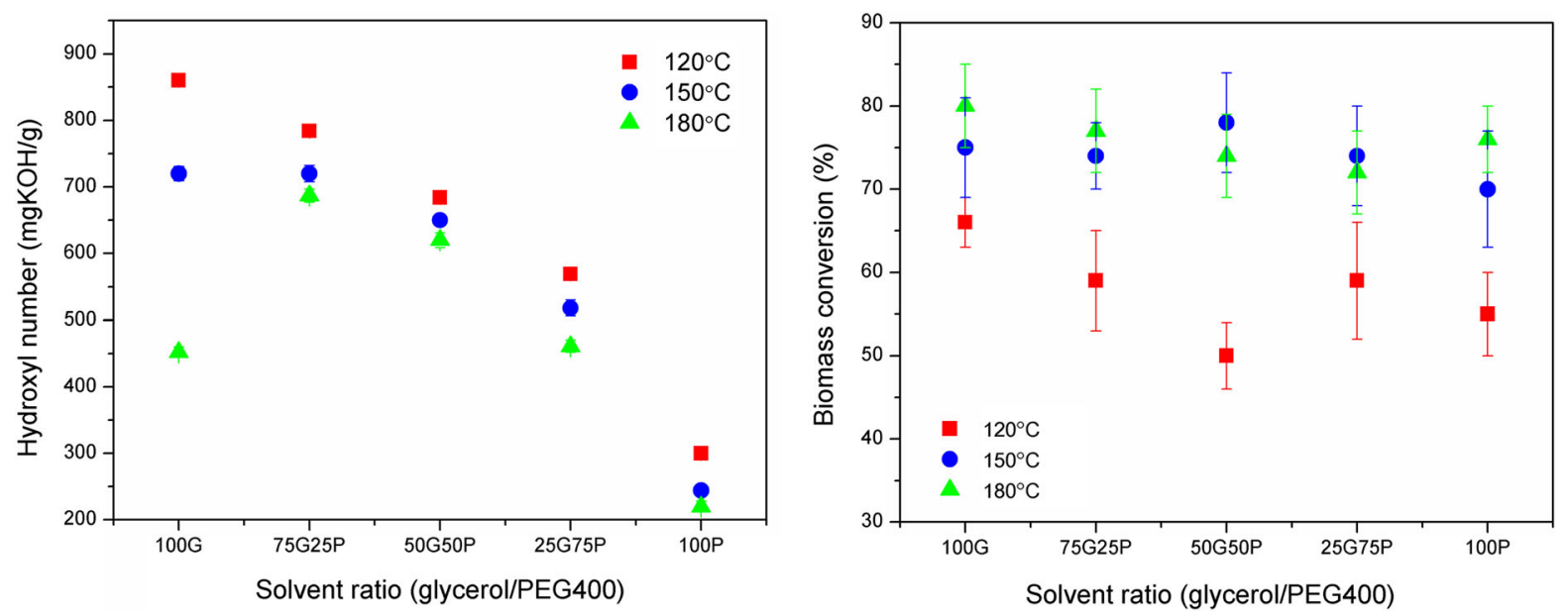

Fig. 4 Changes in the hydroxyl number and biomass conversion after $6 \mathrm{~h}$ of the liquefaction process depending on the solvent used

Figure 4 shows the changes in the hydroxyl number and the degree of biomass conversion at different solvent for reaction time of $6 \mathrm{~h}$.

As the reaction temperature increases, drop of hydroxyl value can be observed. As mentioned above, during the liquefaction process at higher temperatures the solvent condensation reaction takes place. This is particularly evident for a samples containing $100 \mathrm{wt} \%$ of glycerol. It can be observed that biomass conversion increases with increasing reaction temperature (for 100G, 75G25P and 100P samples). In addition, it can be noted that the biomass conversion decreases with the increasing amount of PEG400 in the solvent mixture in addition to sample 50G50P_150. For samples 25G75P and 50G50P initial increase of biomass conversion with reaction temperature was observed, followed by decrease with further increase of temperature. This may suggest that the most preferred reaction temperature for these mixtures of solvents temperature is $150{ }^{\circ} \mathrm{C}$.

In presented study, combinations of two solvents, glycerol and poly(ethylene glycol), in different ratios were used. The solvent content in the final biopolyol accounts for $\sim 90 \%$, thus the values of the hydroxyl number in individual cases are related to the type of solvent used. The glycerol molecule $(\mathrm{Mn}=96 \mathrm{~g} / \mathrm{mol})$ contains three hydroxyl groups, therefore products resulting from the liquefaction of biomass with a large amount of this solvent show high hydroxyl value (in the range of 400-900 $\mathrm{mg} \mathrm{KOH} / \mathrm{g}$ ). The poly(ethylene glycol) molecule (the one used in presented study had $\mathrm{Mn}=400 \mathrm{~g} / \mathrm{mol}$ ) in its structure has two hydroxyl groups, which results in lower hydroxyl values (in the range of 200-400 $\mathrm{mgKOH} / \mathrm{g}$ ), compared to glycerol. As a result, with the increasing content of glycerol in solvent mixture, the hydroxyl number increases (Fig. 4). For a sample containing solely glycerol the largest decrease in the hydroxyl number with the increasing reaction temperature was noted, and the reversed relationship is observed for the biomass conversion. For a $100 \mathrm{G}$ sample, conversion rates at different temperatures are similar (in the range of 66-80\%). The highest biomass conversion value was obtained for 100G sample (80\%) and 50G50P sample (78\%).

Measurements of rheological properties of obtained polyols allowed to determine their viscosity, flow behavior and to match the appropriate mathematical models describing the nature of the liquid.

The viscosity of 100P_180 sample at room temperature was too high, therefore the value shown is the result of the measurement performed at $50{ }^{\circ} \mathrm{C}$. It can be noticed that the viscosity of obtained biopolyols changes as the temperature of the liquefaction reaction increases, which is shown in Fig. 5. As the content of PEG400 in the solvent mixture increases, a decrease in viscosity is observed. This is due to the lower viscosity of PEG400 ( $\eta=0.091 \mathrm{~Pa} \mathrm{~s}$ ) comparing to glycerol $(\eta=0.978 \mathrm{~Pa} \mathrm{~s}$ ) (Yao et al. 1995). A lower viscosity of biopolyols obtained at $150{ }^{\circ} \mathrm{C}$, in comparison to those obtained at temperature of $120^{\circ} \mathrm{C}$ was observed. Comparing the viscosity results with values of hydroxyl number and biomass conversion for polyols obtained at $180{ }^{\circ} \mathrm{C}$, it can be concluded that at this 


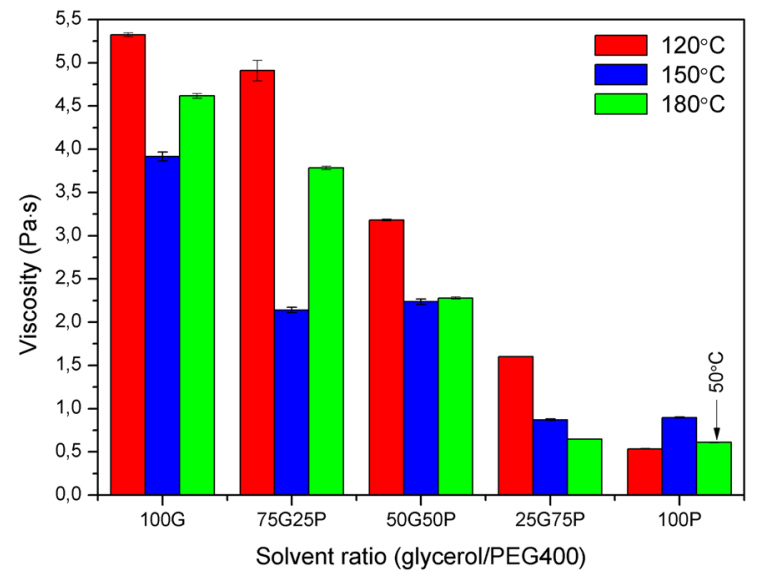

Fig. 5 Viscosity of the obtained biopolyols depending on the composition of the solvent mixture and the liquefaction temperature (shear rate $200 \mathrm{~s}^{-1}$ )

temperature, apart from the liquefaction reaction, condensation of solvents occurs, which was confirmed in other work (Gosz et al. 2018). Higher liquefaction temperatures could result in generation of branched and cyclic oligoglycerols structures, which could affect chain mobility and lead to increased viscosity (Li et al. 2014). Rise of viscosity at higher reaction temperatures could be also associated with the evaporation of volatile compounds (Hu et al. 2012).

Determination of the relationship between shear stress and shear rate provides information on the nature of the liquid. If a given fluid shows linear dependence, it exhibits Newtonian fluid characteristics, and if it is nonlinear, non-Newtonian fluid features (Deshpande et al. 2010).

Figure 6 shows the flow curves for obtained biopolyols. Presented data indicates that polyols obtained via liquefaction of biomass exhibit nonNewtonian fluid properties, because they are characterized by a non-linear dependence of tangential stress on the shear rate. Such dependence is described in Chhabr's work (2010). The tangent of the angle of inclination of the initial flow curve relative to the $\mathrm{x}$-axis is closely related to the dynamic viscosity of the liquid and such a relationship can be described by the following formula (Dziubiński et al. 2009) (4):

$\tan \alpha=\eta_{0}$

Decreasing $\tan \alpha$ value with the increase of the liquefaction temperature results in a decrease in the viscosity of the liquid. Figure 7 shows the viscosity curves for biopolyols obtained at different temperatures after $6 \mathrm{~h}$. For samples 50G50P_180, 25G75P_150, 25G75P_180 and 100P_120 the viscosity increases with increasing shear rate, which indicates their dilatant nature. Viscosity of other biopolyols decreases with increasing shear rate, indicating their pseudoplastic character. For pseudoplastic fluids as the shear rate is increased, the asymmetric molecules undergo gradual ordering, i.e. the flow determines the orientation of the particle axis along the flow line. The viscosity in such liquids decreases as the shear rate increases, initially rapidly, then slower, until the optimal arrangement of particles is achieved. Reducing the viscosity of pseudoplastic fluids under the influence of increased shear rate is also the reason for their determination as so-called shear-thinning liquids (Głowińska and Datta 2014).

The analysis of viscosity curves shows that depending on the solvent used and the temperature of the liquefaction process, polyols show different character, however difficult to clearly determine on the basis of the obtained viscosity curves, therefore an analysis of mathematical models was used. Table 5 presents data on rheological analysis of biopolyols obtained using the models of Ostwald-de Waele and Hershel-Bulkley.

Mathematical models approximate the real behavior of non-Newtonian fluids. The Ostwald-de Waele model is based on the following Eq. (5):

$\tau=K\left(\frac{\partial u}{\partial y}\right)^{n}$

where $\mathrm{K}$-flow consistency index, $\frac{\partial u}{\partial y}$-shear rate perpendicular to the plane of shear, $\mathrm{n}$-flow behavior index.

Knowing the value of the fluid flow exponent, its character can be determined: $\mathrm{n}<1$-pseudoplastic, $\mathrm{n}=1$-Newtonian, $\mathrm{n}>1$-dilatant.

Another model that can be used to describe the type of liquid is the Herschel-Bulkley model, which is described by the following formula (6):

$\tau=\tau_{0}+K \dot{\gamma}^{n}$

where: $\tau$-shear stress, $\tau_{0}$-yield stress, $\dot{\gamma}$-shear rate, $\mathrm{K}$ - flow consistency, $\mathrm{n}$ - flow behavior index.

The flow exponent $n$, as in the Ostwald-de Waele model, determines the nature of the liquid. In the Herschel-Bulkey model, an important parameter is the 

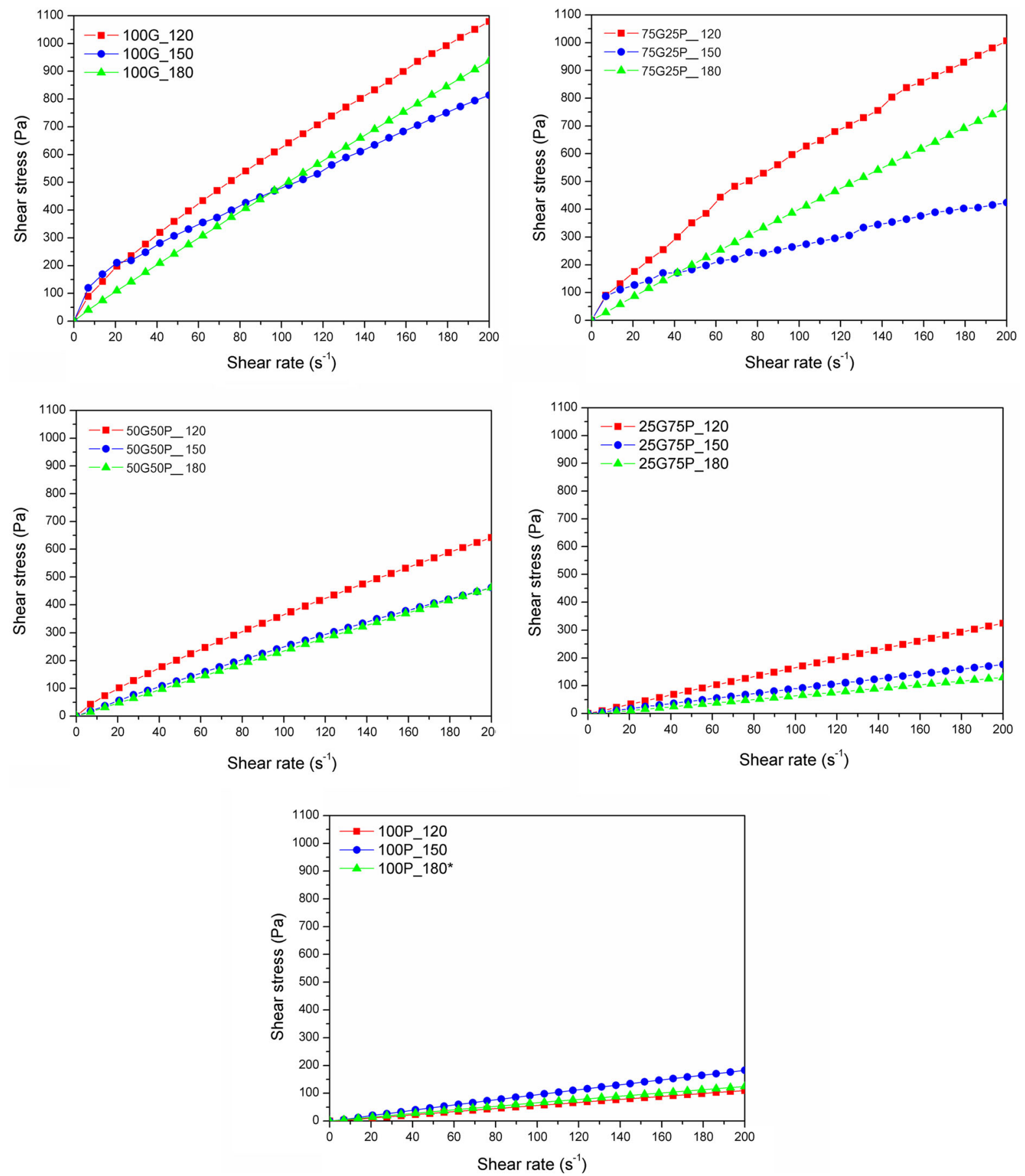

Fig. 6 Biopolyols flow curves $\left(*\right.$ measurement temperature $50{ }^{\circ} \mathrm{C}$ )

plastic shear stress $\tau_{0}$ determining the amount of stress that the liquid must take to start flowing.

Basing on the obtained data, it can be stated that the biopolyols obtained during the liquefaction of biomass show the character of Newtonian and non-Newtonian fluids. Newtonian behavior was observed for following samples: 100G_180, 75G25P_180, 50G50P_150, 50G50P_180, 25G75P_120, 25G75P_150 and 

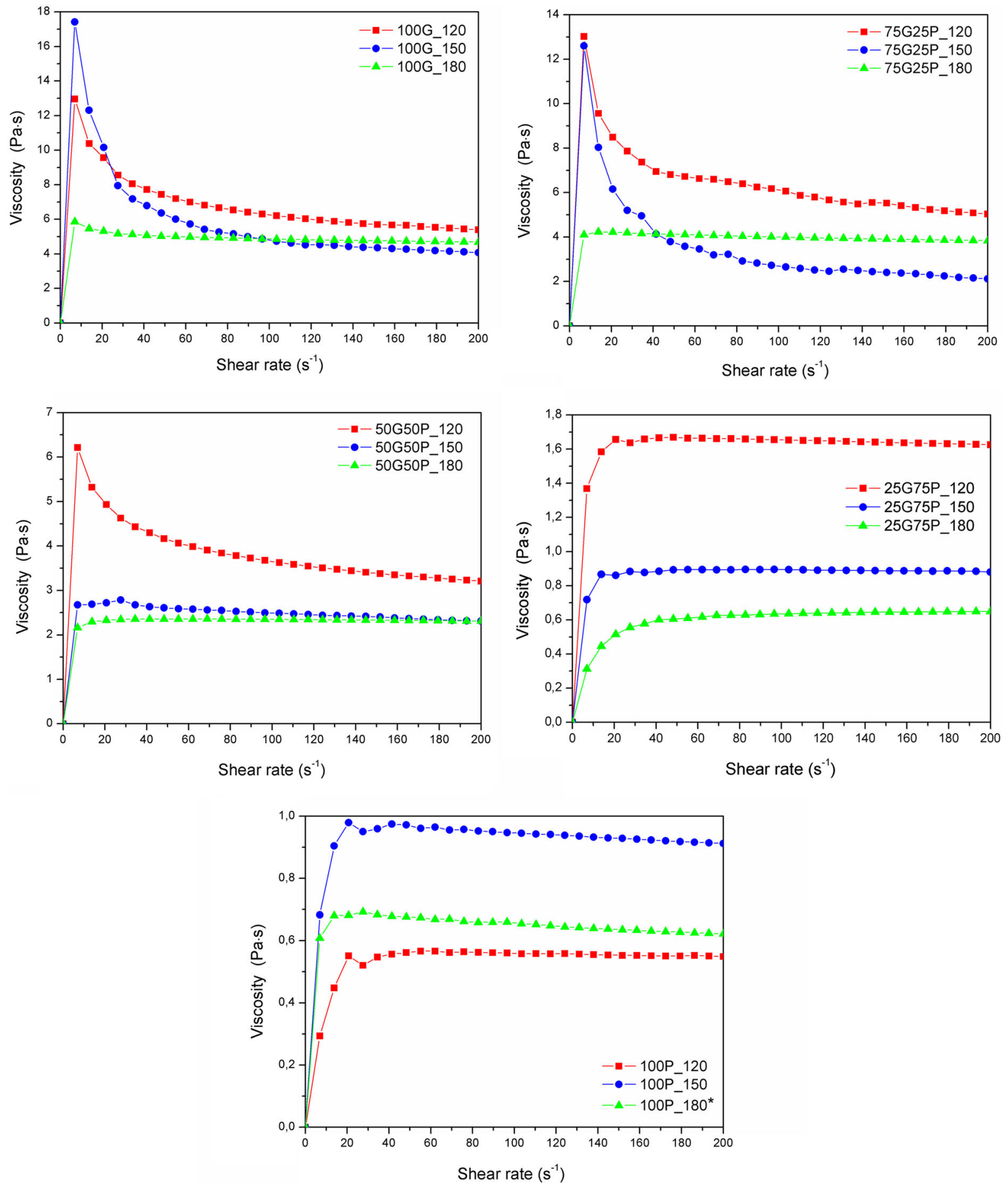

Fig. 7 Viscosity curves of biopolyols (*measurement temperature $50{ }^{\circ} \mathrm{C}$ )

100P_150. Other biopolyols show the character of non-Newtonian fluids. The flow exponent for samples 25G75P_180 and 100P_120 is greater than 1, i.e. they show the nature of shear-thickening fluids. The exponent value for other liquids is lower than 1 and they can be qualified as shear-thinning liquids. 
Table 5 The Ostwald-de Waele and HerschelBulkley linear functions based on the rheological data from biopolyols samples

\begin{tabular}{|c|c|c|c|c|c|}
\hline Biopolyol symbol & Function & $\mathrm{K}\left(\mathrm{Pa} \cdot \mathrm{s}^{\mathrm{n}}\right)$ & \multicolumn{2}{|c|}{$\mathrm{n}(-)$} & $\mathrm{R}^{2}$ \\
\hline \multicolumn{6}{|c|}{ The Ostwald-de Waele linear functions } \\
\hline 100G_120 & $y=94.7254 \cdot x^{0.4028}$ & 94.7254 & \multicolumn{2}{|c|}{0.4028} & 0.9641 \\
\hline 100G_150 & $y=41.153 \cdot x^{0.5214}$ & 41.153 & \multicolumn{2}{|c|}{0.5214} & 0.9810 \\
\hline 100G_180 & $y=5.7297 \cdot x^{0.9598}$ & 5.7297 & \multicolumn{2}{|c|}{0.9598} & 0.9997 \\
\hline 75G25P_120 & $y=70.2075 \cdot x^{0.4441}$ & 70.2075 & \multicolumn{2}{|c|}{0.4441} & 0.9726 \\
\hline 75G25P_150 & $y=58.2793 \cdot x^{0.3424}$ & 58.2793 & \multicolumn{2}{|c|}{0.3424} & 0.9792 \\
\hline 75G25P_180 & $y=4.1783 \cdot x^{0.9840}$ & 4.1783 & \multicolumn{2}{|c|}{0.9840} & 0.9996 \\
\hline 50G50P_120 & $y=9.9206 \cdot x^{0.7828}$ & 9.9206 & \multicolumn{2}{|c|}{0.7828} & 0.9998 \\
\hline 50G50P_150 & $y=2.7818 \cdot x^{0.9622}$ & 2.7818 & \multicolumn{2}{|c|}{0.9622} & 0.9979 \\
\hline 50G50P_180 & $y=2.0712 \cdot x^{1.022}$ & 2.0712 & \multicolumn{2}{|c|}{1.0220} & 0.9996 \\
\hline 25G75P_120 & $\mathrm{y}=1.0379 \cdot \mathrm{x}^{0.983}$ & 1.0379 & \multicolumn{2}{|c|}{0.9830} & 0.9978 \\
\hline 25G75P_150 & $y=1.3775 \cdot x^{1.0331}$ & 1.3775 & \multicolumn{2}{|c|}{1.0331} & 0.9995 \\
\hline 25G75P_180 & $y=x^{0.8982}$ & 1 & \multicolumn{2}{|c|}{0.8982} & 0.9939 \\
\hline 100P_120 & $y=x^{0.8640}$ & 1 & \multicolumn{2}{|c|}{0.8640} & 0.9933 \\
\hline 100P_150 & $y=x^{0.9811}$ & 1 & \multicolumn{2}{|c|}{0.9811} & 0.9996 \\
\hline 100P_180 & $y=x^{0.8991}$ & 1 & \multicolumn{2}{|c|}{0.8991} & 0.9982 \\
\hline Bio-polyol symbol & Function & $\tau_{0}(\mathrm{~Pa})$ & $\mathrm{K}\left(\mathrm{Pa} \mathrm{s}^{\mathrm{n}}\right)$ & $\mathrm{n}(-)$ & $\mathrm{R}^{2}$ \\
\hline \multicolumn{6}{|c|}{ The Herschel Bulkley linear functions } \\
\hline 100G_120 & $\mathrm{y}=57.8516+11.6441 \cdot \mathrm{x}^{0.8419}$ & 57.8516 & 11.6441 & 0.8419 & 0.9986 \\
\hline 100G_150 & $\mathrm{y}=43.4902+8.4646 \cdot \mathrm{x}^{0.8447}$ & 43.4902 & 8.4646 & 0.8447 & 0.9806 \\
\hline 100G_180 & $y=0.0665+5.6944 \cdot x^{0.9609}$ & 0.0665 & 5.6944 & 0.9609 & 0.9988 \\
\hline 75G25P_120 & $\mathrm{y}=51.6182+10.1419 \cdot \mathrm{x}^{0.8458}$ & 51.6182 & 10.1419 & 0.8458 & 0.9994 \\
\hline 75G25P_150 & $y=57.0134+6.1313 \cdot x^{0.7815}$ & 57.0134 & 6.1313 & 0.7815 & 0.9880 \\
\hline 75G25P_180 & $y=4.5163 \cdot x^{0.9673}$ & 0 & 4.5163 & 0.9673 & 0.9984 \\
\hline 50G50P_120 & $y=10.4541+7.5965 \cdot x^{0.8329}$ & 10.4541 & 7.5965 & 0.8329 & 0.9997 \\
\hline 50G50P_150 & $y=3.0562 \cdot x^{0.9423}$ & 0 & 3.0562 & 0.9423 & 0.9908 \\
\hline 50G50P_180 & $\mathrm{y}=2.3385 \cdot \mathrm{x}^{0.9958}$ & 0 & 2.3385 & 0.9958 & 0.9990 \\
\hline 25G75P_120 & $\mathrm{y}=4.7078+0.7831 \cdot \mathrm{x}^{0.9688}$ & 4.7078 & 0.7831 & 0.9688 & 0.9900 \\
\hline 25G75P_150 & $y=1.6047 \cdot x^{1.0004}$ & 0 & 1.6047 & 1.0004 & 0.9985 \\
\hline 25G75P_180 & $\mathrm{y}=0.4953 \cdot \mathrm{x}^{1.0514}$ & 0 & 0.4953 & 1.0514 & 0.9997 \\
\hline 100P_120 & $y=0.5045 \cdot x^{1.0134}$ & 0 & 0.5045 & 1.0134 & 0.9970 \\
\hline 100P_150 & $\mathrm{y}=1.0418 \cdot \mathrm{x}^{0.9730}$ & 0 & 1.0418 & 0.973 & 0.9984 \\
\hline 100P_180 & $y=0.751 \cdot x^{0.9617}$ & 0 & 0.751 & 0.9617 & 0.9970 \\
\hline
\end{tabular}

Analyzing the results in terms of matching the appropriate model to the liquid, the correlation coefficient $\mathrm{R}^{2}$ is an important parameter. The more its value is close to 1 , the model better describes the behavior of particular liquid. Most of analyzed biopolyols except 100G_120, 75G25P_120, 75G25P_150,25G75P_180 and 100P_120 were better described by the Ostwald-de Waele model.

Figure 8 shows the FTIR spectra of biomass, 50G50P solvent mixture and 50G50P_150 biopolyol.
Most of the signals obtained on the biopolyol spectrum correlate with signals from solvents due to their high content $(90 \mathrm{wt} \%)$ in polyol.

However, one can observe changes in the intensity of signals, mainly the signal responsible for the vibrations of the hydroxyl group in the range $3300-3400 \mathrm{~cm}^{-1}$ (Deng and Ting 2005). The intensity of this signal decreased for biopolyol 50G50P_150 comparing to the intensity of the signal for solvents and biomass, which confirms the occurrence of 


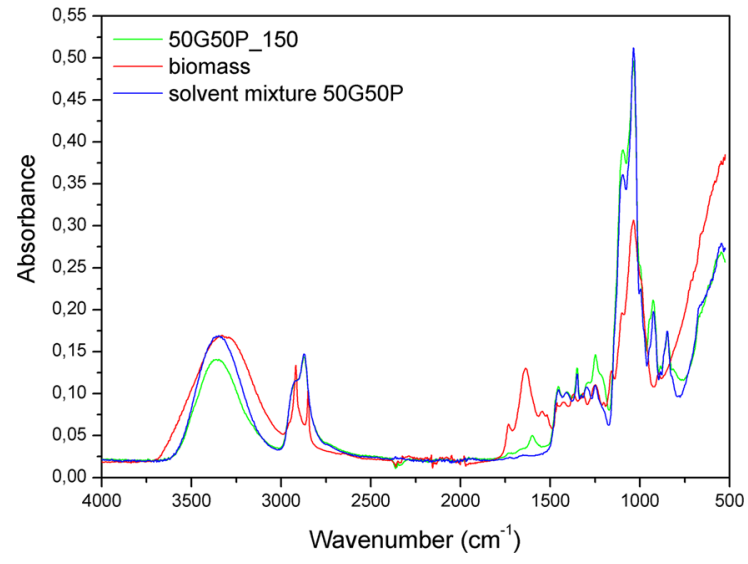

Fig. 8 FTIR spectra of 50G50P_150 biopolyol, used biomass and solvents

reaction between substrates and correlates with the decreasing value of the hydroxyl number. In addition, the appearance of new bands for biopolyol at 1733 and $1602 \mathrm{~cm}^{-1}$ is observed, which may correspond to $\mathrm{C}=\mathrm{O}$ and $\mathrm{C}=\mathrm{C}$ bonds in biomass degradation products generated during liquefaction process (Budarin et al. 2010). The signal at $1733 \mathrm{~cm}^{-1}$ may also come from levulinate formed as a result of the reaction shown in Fig. 2. (Grilc et al. 2015). The remaining signals observed in the spectra were assigned to appropriate chemical bonds and vibrations and are presented in Table 6.

Figure 9 shows the FTIR spectra of solvents and biopolyols obtained at three temperatures. Generally, all biopolyols exhibit absorption signals similar to the solvents from which they were obtained. For all samples, decrease in the intensity of the absorbance band related to vibrationsof hydroxyl groups (approximately $3300 \mathrm{~cm}^{-1}$ ) is observed with the increase of the reaction temperature (in addition to biopolyols obtained as a result of liquefaction of PEG400). For these samples, the intensity of the band derived from the vibrations of the hydroxyl group is similar to the intensity of the signal from the solvent. In the range of $1750-1700 \mathrm{~cm}^{-1}$ for all biopolyols (except for 100P), the appearance of the absorption band characteristic for the $\mathrm{C}=\mathrm{O}$ group vibrations is observed. As mentioned above, this may correspond to the vibrations of the levulinate carbonyl group that may be formed during the liquefaction reaction (Fig. 2).

Figure 10 shows the water content in biopolyols depending on the solvent used. Water content in biopolyols obtained at $120{ }^{\circ} \mathrm{C}$ is in the range of $1.7-2.2 \%$, for $150{ }^{\circ} \mathrm{C}$ in the range of $2.5-3.7 \%$ and for $180{ }^{\circ} \mathrm{C}$ in the range of $5.8-8.4 \%$.

Table 6 The values of the wavenumbers of the appropriate functional groups for the FTIR spectra

\begin{tabular}{|c|c|c|c|}
\hline \multirow[t]{2}{*}{ Vibration (bond) } & \multicolumn{3}{|l|}{ Wavenumber $\left(\mathrm{cm}^{-1}\right)$} \\
\hline & Solvent mixture 50G50P & Biomass from sea & Biopolyol 50G50P_150 \\
\hline Stretching $(\mathrm{O}-\mathrm{H})$ & 3351 & 3320 & 3362 \\
\hline Asymmertic stretching $(\mathrm{C}-\mathrm{H})$ & 2926 & 2921 & 2926 \\
\hline Asymmertic stretching $(\mathrm{C}-\mathrm{H})$ & 2869 & 2853 & 2869 \\
\hline Stretching $(\mathrm{C}=\mathrm{O})$ & - & 1733 & 1733 \\
\hline Stretching $(\mathrm{C}=\mathrm{C})$ & - & 1634 & 1602 \\
\hline Bending $(\mathrm{C}-\mathrm{H})$ & 1453 & 1467 & 1455 \\
\hline Bending $(\mathrm{C}-\mathrm{OH})$ & 1409 & 1422 & 1409 \\
\hline \multicolumn{4}{|l|}{ bending $(\mathrm{C}-\mathrm{H})$} \\
\hline Bending $(\mathrm{C}-\mathrm{OH})$ and $(\mathrm{C}-\mathrm{H})$ & 1350 & 1370 & 1350 \\
\hline Wagging $(\mathrm{C}-\mathrm{H})$ & 1248 & 1248 & 1248 \\
\hline Stretching $(\mathrm{C}-\mathrm{O}-\mathrm{C})$ & - & 1157 & - \\
\hline Stretching $(\mathrm{C}-\mathrm{O}-\mathrm{C})$ and $(\mathrm{C}-\mathrm{O})$ & 1095 & 1099 & 1095 \\
\hline Stretching $(\mathrm{C}-\mathrm{O})$ & 1035 & 1035 & 1035 \\
\hline Stretching $(\mathrm{C}-\mathrm{OH})$ & 924 & - & 924 \\
\hline Rocking $(\mathrm{C}-\mathrm{C})$ & 849 & - & 849 \\
\hline
\end{tabular}



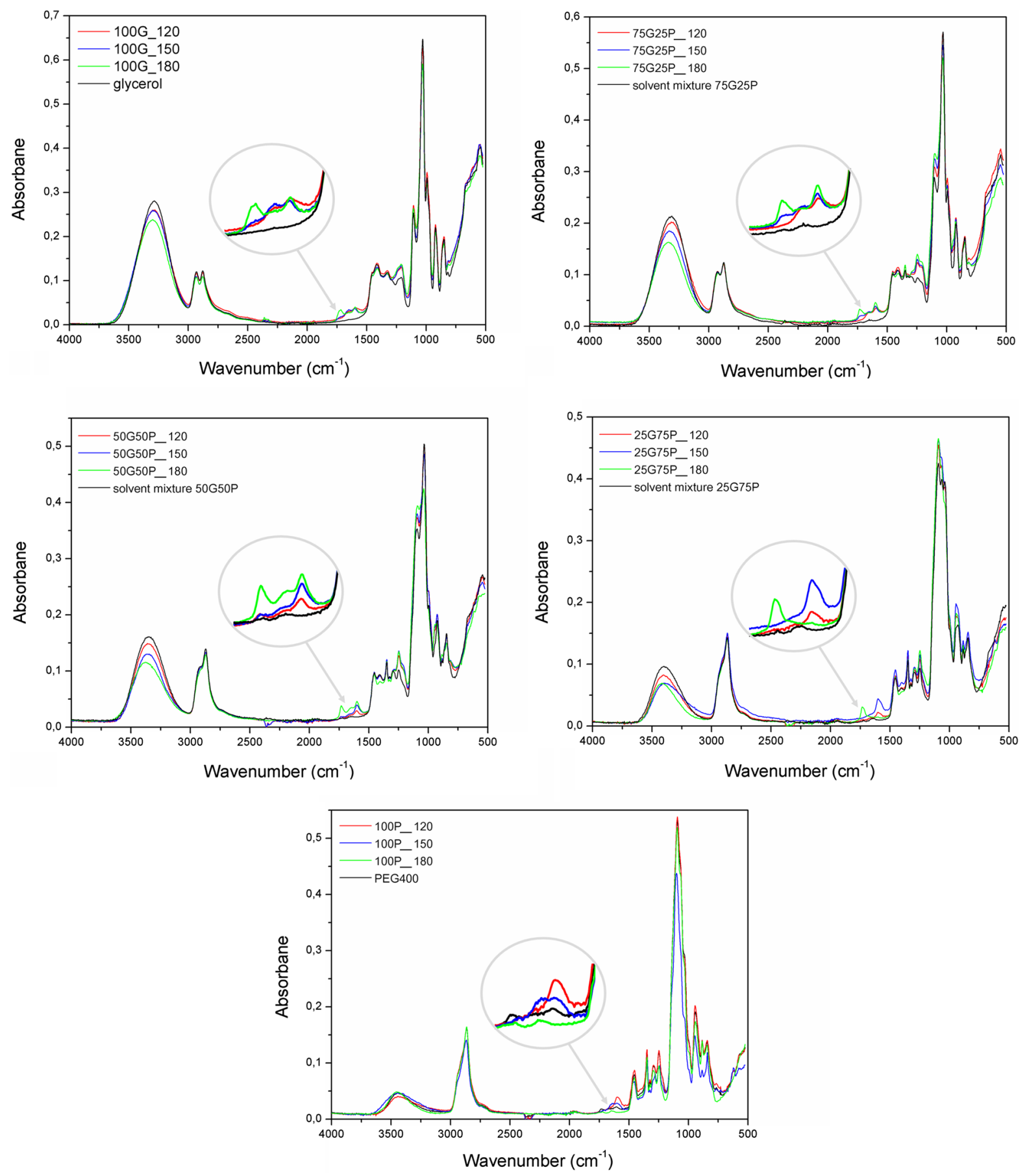

Fig. 9 FTIR spectra of biopolyols showing dependence of the liquefaction temperature and the type of solvent on the chemical structure

Considering that the initial water content in biomass is $9.8 \%$, in crude glycerol $0.5 \%$, and taking into account the water contained in the catalyst, the theoretical water content in biopolyols should equal
$1.44 \%, 1.39 \%, 1.35 \%, 1.31 \%$ and $1.27 \%$, respectively for $100 \mathrm{G}, 75 \mathrm{G} 25 \mathrm{P}, 50 \mathrm{G} 50 \mathrm{P}, 25 \mathrm{G} 75 \mathrm{P}$ and $100 \mathrm{P}$ samples. The obtained biopolyols are characterized by a higher than theoretical water content, which 


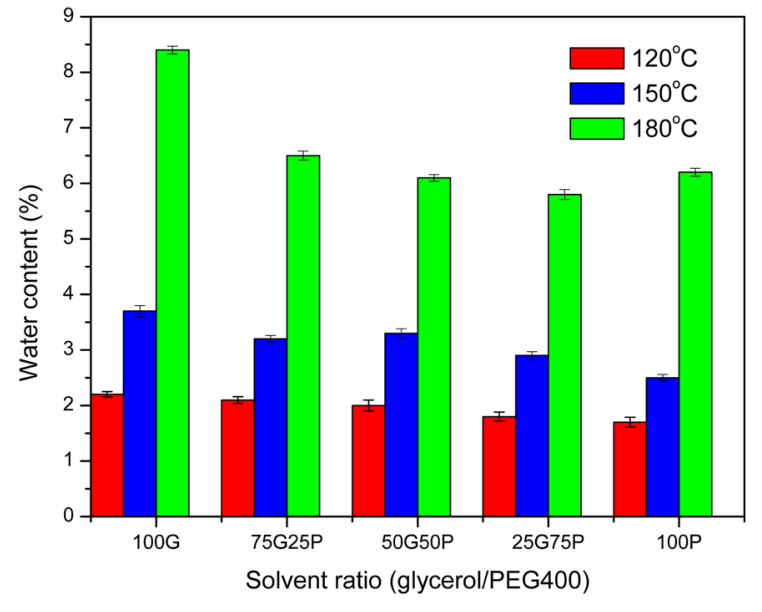

Fig. 10 Water content in biopolyols depending on the solvent and the liquefaction temperature

indicates the formation of water as a by-product. Similar observations were made by Wang et al. (2009). As the temperature of the liquefaction reaction increases, a larger amount of water, a by-product, is observed, which indicates higher reaction efficiency.

All polyols were characterized by low $\mathrm{pH}$ in the range of 1-2. This was due to the use of sulfuric acid as a catalyst. Both low $\mathrm{pH}$ and high-water content are disadvantageous for polyol compounds to be a component for obtaining rigid polyurethane foams. To change these parameters, all biopolyols were neutralized with an aqueous $\mathrm{NaOH}$ solution and dried under reduced pressure. Finally, biopolyols were characterized by a $\mathrm{pH}$ in the range of $6.5-7$ and a water content in the range of $0.2-0.5 \%$.

\section{Characterization of rigid polyurethane foams}

The mixing times and the tack-free time for all PUR foams were $10 \mathrm{~s}$ and $0 \mathrm{~s}$, respectively, therefore in Table 7 only the rise times and the maximum
Table 7 Rise times and maximum temperatures recorded during the synthesis of PUR foams

\begin{tabular}{llc}
\hline Biopolyol content (pbw) & Rise time $(\mathrm{s})$ & $\mathrm{T}_{\mathrm{MAX}}\left({ }^{\circ} \mathrm{C}\right)$ \\
\hline 0 & 40 & 86.8 \\
10 & 40 & 87.9 \\
20 & 39 & 138.2 \\
30 & 38 & 141.6 \\
\hline
\end{tabular}

temperatures recorded during the synthesis are presented. At the same time, a slight decrease in the rise time and the increase in the maximum reaction temperature with the increase of LB biopolyol (50G50P_150) content in the foam formulation were observed. A large increase in $\mathrm{T}_{\mathrm{MAX}}$ is observed for foams containing more than $20 \%$ of the LB biopolyol, which indicates enhanced reactivity of these systems. A similar relationship was confirmed in other studies (Kosmela et al. 2017a, b).

The properties of rigid polyurethane foams depend on their apparent density, so it is important to analyze materials with similar apparent density. Table 8 presents apparent density, sol fraction content, compressive strength and glass transition temperatures (determined from the temperature dependence of loss tangent $(\tan \delta)$ (DMA)) of PUR foams. Apparent density of all foams was in the range of $49.2-50.8 \mathrm{~kg} /$ $\mathrm{m}^{3}$. Such values have been achieved by modifying the foam formulations. The addition of biopolyol LB resulted in a reduction of the sol fraction content for all foams, which indicates a reduction in the amount of non-crosslinked fraction and may suggest a higher crosslink density. In addition to the main reaction occurring during the production of PUR foams, other reactions are generated that can contribute to the increase of crosslink density of materials. These are

Table 8 Physico-mechanical and thermal properties of PUR foams

\begin{tabular}{|c|c|c|c|c|c|}
\hline \multirow[t]{2}{*}{ Foam symbol } & \multirow[t]{2}{*}{ Apparent density $\left(\mathrm{kg} / \mathrm{m}^{3}\right)$} & \multirow[t]{2}{*}{ Sol fraction (wt. \%) } & \multicolumn{2}{|c|}{ Compressive strength $(\mathrm{kPa})$} & \multirow[t]{2}{*}{$\mathrm{T}_{\mathrm{g}}\left({ }^{\circ} \mathrm{C}\right)$} \\
\hline & & & Perpendicular & Parallel & \\
\hline 200_LB0 & $49.2 \pm 1.8$ & $2.7 \pm 0.7$ & $163 \pm 9$ & $394 \pm 12$ & 154 \\
\hline 200_LB10 & $50.1 \pm 1.1$ & $2.2 \pm 0.2$ & $176 \pm 10$ & $410 \pm 8$ & 200 \\
\hline 200_LB20 & $50.8 \pm 1.9$ & $1.5 \pm 0.3$ & $229 \pm 8$ & $430 \pm 11$ & 204 \\
\hline 200_LB30 & $49.6 \pm 1.3$ & $1.3 \pm 0.7$ & $287 \pm 11$ & $446 \pm 8$ & 210 \\
\hline
\end{tabular}


reactions in which allophanate, biuret groups and isocyanate trimerization products are formed.

Table 8 shows the values of compressive strength of foams for $15 \%$ of deformation. Foams were compressed in two orientations, perpendicular and parallel to the direction of foam growth. It was noted that the cellular structure has a significant impact on mechanical strength. Compression of foams in a direction parallel to the growth of the foams resulted in higher compressive strength values, comparing to results obtained for the perpendicular direction, which was confirmed in other works (Modesti and Lorenzetti 2003). In general, the increase of LB biopolyol content in foams increased their strength. This may be associated with larger crosslink density of foams, which is confirmed by the values of the sol fraction content. Other researchers have described similar relationships (Guo et al. 2015).

Table 8 also presents the glass transition temperatures $\left(T_{g}\right)$ for the PUR foams. The increase in $T_{g}$ is observed along with the increase of the amount of biopolyol, which suggests stiffening of the material. Javni et al. (2004) found that the increase in $T_{g}$ of PUR foams along with the increase in biopolyol in formulations is due to the lower flexibility of the biopolyol chains comparing to petrochemical polyols and contributes to a higher density of cross-linking of materials.

The FTIR analysis showed that the addition of biopolyol does not significantly affect the structure of the foams (Fig. 11). Absorption bands in the range of $3290-3320 \mathrm{~cm}^{-1}$ were assigned to stretching of $\mathrm{N}-\mathrm{H}$ bonds in urethane groups. The bending vibrations of these bonds were confirmed by signals the range of $1510-1520 \mathrm{~cm}^{-1}$ (Sormana and Meredith 2004). Bands in the range of $1705-1715 \mathrm{~cm}^{-1}$ were assigned to stretching vibrations of $\mathrm{C}=\mathrm{O}$ groups. In the $1200-1215 \mathrm{~cm}^{-1}$ range, the occurring bands can be attributed to the $\mathrm{C}-\mathrm{N}$ bond stretching in urethane groups (Fournier and Du Prez 2008). The signals described above confirm the presence of urethane groups. The absorption bands around $1410-1415 \mathrm{~cm}^{-1}$ are associated with the presence of isocyanurate rings (Samborska-Skowron and Balas 2003). Signals observed in the range of $2260-2280 \mathrm{~cm}^{-1}$ indicate the presence of free $\mathrm{N}=\mathrm{C}=\mathrm{O}$ groups, which is associated with a high value of the isocyanate index (excess of isocyanate) (Jiao et al. 2013). In the wavelength ranges of 2960-2975

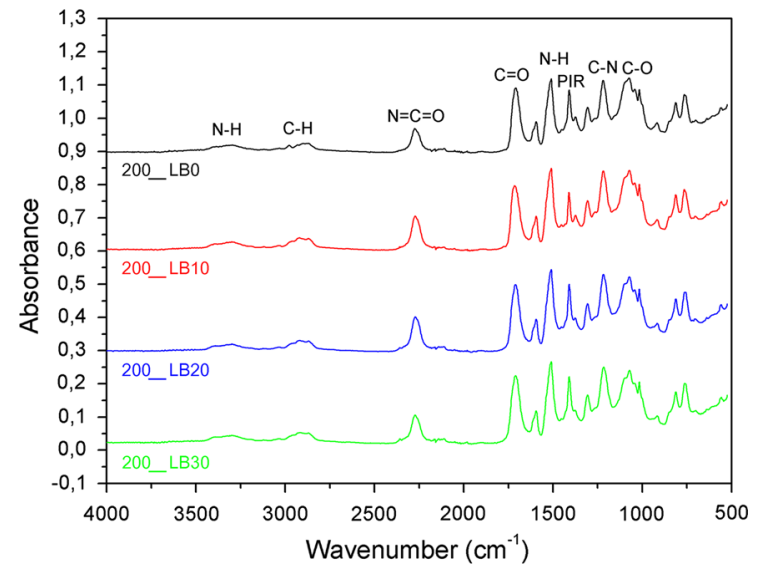

Fig. 11 FTIR spectra of obtained PUR foams

and 2860-2870 $\mathrm{cm}^{-1}$, signals responsible for asymmetric and symmetric stretching vibrations of $\mathrm{C}-\mathrm{H}$ bonds in the methylene groups of the polymer chains are observed. Multiple signals in the range of $1000-1090 \mathrm{~cm}^{-1}$ are associated with vibrations of $\mathrm{C}-\mathrm{O}$ bonds in the ester and ether groups of the polyols (Pretsch et al. 2009).

\section{Conclusion}

The work presents the method of obtaining biopolyol in a one-stage process of marine biomass liquefaction with crude glycerol and poly(ethylene glycol). The influence of process parameters on the hydroxyl number, biomass conversion, products' structure and their rheological properties are discussed. It was found that as the temperature rises, the hydroxyl number decreases and the biomass conversion increases, which indicates the progress of the reaction. Depending on the solvents used, the reaction took place at different rates. For the mixture of solvents containing crude glycerol, the appearance of an absorbance band that can be derived from levulinate carbonyl groups was observed, which may confirm the occurrence of the proposed reaction (Fig. 2). As the reaction temperature increased, the viscosity of the biopolyols changed. For all the solvents used, the viscosity of the liquefied biomass decreased at reaction temperatures of at most $150{ }^{\circ} \mathrm{C}$, above this temperature the viscosity increased, which could be due to condensation of the solvents and formation of branched structures. Depending on the solvent used, biopolyols exhibited 
different rheological properties. The majority of biopolyols showed the nature of shear-thinning liquid, which is advantageous from the application point of view. With the increase of the liquefaction temperature, increase of the water content in the obtained biopolyols was observed, which confirms a greater extent of reaction. It has been found that as the content of PEG400 in the solvent mixture increases, less water is formed as a by-product of the reaction. This may be due to the lower reactivity of PEG400 comparing to crude glycerol. Finally, it was found that the most preferred properties are showed by biopolyol obtained after $6 \mathrm{~h}$ at $150{ }^{\circ} \mathrm{C}$ and using a 50G50P solvent mixture.

The biopolyol obtained under the above-mentioned conditions was used to obtain rigid polyurethane foams, as the substitution of the petrochemical polyol in the formulation. A maximum of $30 \mathrm{wt} \%$ of biopolyol was incorporated into foam formulation. It was found that the addition of biopolyol resulted in a shorter foam rise time and a higher temperature increase during the synthesis, which indicates increased reactivity of the system. The introduction of biopolyol into the formulation also influenced the mechanical properties of the foams. Foams obtained with the biopolyol had a higher compressive strength and a higher glass transition temperature, which could have been caused by a greater stiffening of the material. Spectroscopic analysis confirmed the presence of polyurethane groups and isocyanurate rings in foams. Generally, it can be stated that the addition of the biopolyol obtained in an amount up to $30 \mathrm{wt} \%$. does not significantly change the properties of PUR foams, and even improves compressive strength. This is a big advantage in terms of its potential use in the production of polyurethanes.

Open Access This article is distributed under the terms of the Creative Commons Attribution 4.0 International License (http:// creativecommons.org/licenses/by/4.0/), which permits unrestricted use, distribution, and reproduction in any medium, provided you give appropriate credit to the original author(s) and the source, provide a link to the Creative Commons license, and indicate if changes were made.

\section{References}

Bergel BF, Dias Osorio S, da Luz LM, Santana RMC (2018) Effects of hydrophobized starches on thermoplastic starch foams made from potato starch. Carbohydr Polym
200:106-114. https://doi.org/10.1016/j.eurpolymj.2018. 08.001

Bi H, Ren Z, Guo R, Xu M, Song Y (2018) Fabrication of flexible wood flour/thermoplastic polyurethane elastomer composites using fused deposition molding. Ind Crop Prod 122:76-84. https://doi.org/10.1016/j.indcrop.2018.05.059

Briand X, Cluzet S, Dumas B, Esquerre-Tugaye MT, Salamagne S (2005) Use of ulvans as elicitors of mechanisms for nitrogen absorption and protein synthesis. WO2005094581A1

Budarin VL, Clark JH, Lanigan BA, Shuttleworth P, Macquarrie DJ (2010) Microwave assisted decomposition of cellulose: a new thermochemical route for biomass exploitation. Bioresour Technol 101:3776-3779. https://doi.org/10. 1016/j.biortech.2009.12.110

Cabello-Pasini A, Muñiz-Salazar R, Ward DH (2004) Biochemical characterization of the seagrass Zostera marina at its southern distribution limit in the North Pacific. Cienc Mar 30:21-34. https://doi.org/10.7773/cm.v30i11.123

Chen HB, Shen P, Chen MJ, Zhao HB, Schiraldi DA (2016) Highly efficient flame retardant polyurethane foam with alginate/clay aerogel coating. ACS Appl Mater Interfaces 8(47):32557-32564. https://doi.org/10.1021/acsami. $6 \mathrm{~b} 11659$

Chhabra RP (2010) Non-Newtonian fluids: an introduction. In: Deshpande AP, Krishnan JM, Kumar S (eds) Rheology of complex fluids. Springer, Berlin, pp 3-34

Davies P, Morvan C, Sire O, Baley C (2007) Structure and properties of fibers from sea-grass (Zostera marina). J Mater Sci 13(42):4850-4857. https://doi.org/10.1007/ s10853-006-0546-1

Deng S, Ting YP (2005) Characterization of PEI-modified biomass and biosorption of $\mathrm{Cu}(\mathrm{II}), \mathrm{Pb}(\mathrm{II})$ and $\mathrm{Ni}(\mathrm{II})$. Water Res 39:2167-2177. https://doi.org/10.1016/j.watres.2005. 03.033

Deshpande AP, Krishnan JM, Kumar S (2010) Reology of complex fluids. Springer, New York

Dhaliwala GS, Anandana S, Chandrashekharaa K, Leesb J, Namb P (2018) Development and characterization of polyurethane foams with substitution of polyether polyol with soy-based polyol. Eur Polym J 107:105-117. https:// doi.org/10.1016/j.eurpolymj.2018.08.001

Dziubiński M, Kiljanski T, Sęk J (2009) Podstawy reologii i reometrii płynów. Lodz Unversity of Technology Publisher, Lodz

Fournier D, Du Prez F (2008) "Click" chemistry as a promising tool for side-chain functionalization of polyurethanes. Macromolecules 41:4622-4630. https://doi.org/10.1021/ ma800189z

Głowińska E, Datta J (2014) A mathematical model of rheological behavior of novel bio-based isocyanate-terminated polyurethane prepolymers. Ind Crop Prod 60:123-129. https://doi.org/10.1016/j.indcrop.2014.06.016

Gosz K, Kosmela P, Hejna A, Gajowiec G, Piszczyk Ł (2018) Biopolyols obtained via microwave-assisted liquefaction of lignin: structure, rheological, physical and thermal properties. Wood Sci Technol 52:599-617. https://doi.org/ 10.1007/s00226-018-0991-4

Grilc M, Likozar B, Levec J (2015) Biofuel from lignocellulosic biomass liquefaction in waste glycerol and its catalytic 
upgrade. In: Dell G, Egger CH (eds) World sustainable energy days next 2014. Springer, Wiesbaden, pp 137-144

Guo H, Gao Q, Ouyang C, Zheng K, Xu W (2015) Research on properties of rigid polyurethane foam with heteroaromatic and brominated benzyl polyols. J Appl Polym Sci 132:1-8. https://doi.org/10.1002/app.42349

Guo R, Ren Z, Bi H, Song Y, Xu M (2018) Effect of toughening agents on the properties of poplar wood flour/poly(lactic acid) composites fabricated with fused deposition modeling. Euro Polym J 107:34-45. https://doi.org/10.1016/j. eurpolymj.2018.07.035

Halal SLME, Colussi R, Deon VG, Pinto VZ, Villanova FA, Carreno NLV, Dias ARG, Zavareze ER (2015) Films based on oxidized starch and cellulose from barley. Carbohydr Polym 133:644-653. https://doi.org/10.1016/j.carbpol. 2015.07.024

Hejna A, Kosmela P, Klein M, Formela K, Kopczyńska M, Haponiuk JT, Piszczyk $Ł$ (2018a) Two-step conversion of crude glycerol generated by biodiesel production into biopolyols: synthesis, structural and physical chemical characterization. J Polym Environ. https://doi.org/10.1007/ s10924-018-1217-4

Hejna A, Kosmela P, Klein M, Gosz K, Formela K, Haponiuk J, Piszczyk $Ł$ (2018b) Rheological properties, oxidative and thermal stability, and potential application of biopolyols prepared via two-step process from crude glycerol. Polym Degrad Stab 152:29-42. https://doi.org/10.1016/j. polymdegradstab.2018.03.022

Hemamalini T, Dev VRG (2018) Comprehensive review on electrospinning of starch polymer for biomedical applications. Int J Biol Macromol 106:712-718. https://doi.org/10. 1016/j.ijbiomac.2017.08.079

Hu S, Wan C, Li Y (2012) Production and characterization of biopolyols and polyurethane foams from crude glycerol based liquefaction of soybean straw. Bioresour Technol 103:227-233. https://doi.org/10.1016/j.biortech.2011.09. 125

Javni I, Zhang W, Petrović ZS (2004) Soybean-oil-based polyisocyanurate rigid foams. $\mathrm{J}$ Polym Environ 12:123-129. https://doi.org/10.1023/B:JOOE. 0000038543.77820.be

Jiao L, Xiao H, Wang Q, Sun J (2013) Thermal degradation characteristics of rigid polyurethane foam and the volatile products analysis with TG-FTIR-MS. Polym Degrad Stab 98:2687-2696. https://doi.org/10.1016/j.polymdegradstab. 2013.09.032

Jo J, Ly HV, Kim J, Kim SS, Lee EY (2015) Preparation of biopolyol by liquefaction of palm kernel cake using PEG\#400 blended glycerol. J Ind Eng Chem 29:304-313. https://doi.org/10.1016/j.jiec.2015.04.010

Karimia MB, Khanbabaeib G, Sadeghi GMM (2017) Vegetable oil-based polyurethane membrane for gas separation. J Membr Sci 527:198-206. https://doi.org/10. 1016/j.memsci.2016.12.008

Kim KH, Jo YJ, Lee CG, Lee E (2015) Solvothermal liquefaction of microalgal Tetraselmis sp. biomass to prepare biopolyols by using PEG\#400-blended glycerol. Algal Res 12:539-544. https://doi.org/10.1016/j.algal.2015.08.007

Kosmela P, Hejna A, Formela K, Haponiuk JT, Piszczyk Ł (2017a) The study on application of biopolyols obtained by cellulose biomass liquefaction performed with crude glycerol for the synthesis of rigid polyurethane foams. J Polym Environ 26:2546-2554. https://doi.org/10.1007/ s10924-017-1145-8

Kosmela P, Kazimierski P, Formela K, Haponiuk JT, Piszczyk $Ł$ (2017b) Liquefaction of macroalgae enteromorpha biomass for the preparation of biopolyols by using crude glycerol. J Ind Eng Chem 56:399-406. https://doi.org/10. 1016/j.jiec.2017.07.037

Kuruppalil Z (2011) Green plastics: an emerging alternative for petroleum-based plastics? Int J Eng Res Innov 3:59-64

Li C, Luo X, Li T, Tong X, Li Y (2014) Polyurethane foams based on crude glycerol-derived biopolyols: one-pot preparation of biopolyols with branched fatty acid ester chains and its effects on foam formation and properties. Polymer 55:6529-6538. https://doi.org/10.1016/j.polymer. 2014.10.043

Luchese CL, Spada JC, Tessaro IC (2017) Starch content affects physicochemical properties of corn and cassava starchbased films. Ind Crop Prod 109:619-626. https://doi.org/ 10.1016/j.indcrop.2017.09.020

Mayfield S (2015) Consortium for algal biofuel commercialization (CAB-COMM). University of California, San Diego

Modesti M, Lorenzetti A (2001) An experimental method for evaluating isocyanate conversion and trimer formation in polyisocyanate-polyurethane foams. Eur Polym J 37(5):949-954. https://doi.org/10.1016/S00143057(00)00209-3

Modesti M, Lorenzetti A (2003) Improvement on fire behaviour of water blown PIR-PUR foams: use of anhalogen-free flame retardant. Eur Polym J 39:263-268. https://doi.org/ 10.1016/S0014-3057(02)00198-2

Nouraddini M, Esmaiili M, Mohtarami F (2018) Development and characterization of edible films based on eggplant flour and corn starch. Int J Biol Macromol 120:1639-1645. https://doi.org/10.1016/j.ijbiomac.2018.09.126

Oh ST, Kim WR, Kim SH, Chung YC, Park JS (2011) The preparation of polyurethane foam combined with $\mathrm{pH}$-sensitive alginate/bentonite hydrogel. Fibers Polym 12(2):159-165. https://doi.org/10.1007/s12221-011-01594

Pathak S, Sneha CLR, Mathew BB (2014) Bioplastics: its timeline based scenario \& challenges. J Polym Biopolym Phys Chem 2:84-90

Pawar MS, Kadam AS, Dawane BS, Yemul OS (2016) Synthesis and characterization of rigid polyurethanefoams from algae oil using biobased chain extenders. Polym Bull 73:727-741. https://doi.org/10.1007/s00289-015-1514-1

Piszczyk Ł, Kosmela P, Hejna A, Haponiuk JT (2017) Sposób wytwarzania przyjaznych środowisku nowych hydroksypochodnych, P.420608

Pretsch T, Jakob I, Müller W (2009) Hydrolytic degradation and functional stability of a segmented shape memory poly(ester urethane). Polym Degrad Stab 94:61-73. https://doi. org/10.1016/j.polymdegradstab.2008.10.012

Ruddick C, Fishman BD (2015) World's first algae surfboard makes waves in San Diego. University of California, San Diego

Samborska-Skowron R, Balas A (2003) Jakościowa identyfikacja pierścieni izocyjanurowych $\mathrm{w}$ elastomerach 
uretanowo-izocyjanurowych i w ich hydrolizatach. Polimery 48:371-374

Sormana JL, Meredith JC (2004) High-throughput discovery of structure-mechanical property relationships for segmented poly(urethane-urea)s. Macromolecules 37:2186-2195. https://doi.org/10.1021/ma035385v

Stevens ES (2003) What makes green plastic green? Biocycle 44:24-27

Suriyamongkol P, Weselake R, Narine S, Moloney M, Shah S (2007) Biotechnological approaches for the production of polyhydroxyalkanoates in microorganisms and plants-a review. Biotechnol Adv 25:148-175. https://doi.org/10. 1016/j.biotechadv.2006.11.007

Ubeyitogullari A, Ciftci ON (2016) Formation of nanoporous aerogels from wheat starch. Carbohydr Polym 147:125-132. https://doi.org/10.1016/j.carbpol.2016.03. 086

Wang Y, Wu J, Wan Y, Lei H, Yu F, Chen P, Lin X, Liu Y, Ruan $R$ (2009) Liquefaction of corn stover using industrial biodiesel glycerol. Int J Agric Biol Eng 2(2):32-40. https:// doi.org/10.3965/j.issn.1934-6344.2009.02.032-040

Yamada T, Hu YH, Ono H (2001) Condensation reaction of degraded lignocellulose during wood liquefaction in the presence of polyhydric alcohols. Nippon Setchaku Gakkaishi 37:471-478. https://doi.org/10.11618/adhesioj.37. 471
Yao Y, Yoshioka M, Shiraishi N (1995) Rigid polyurenthane foams from liquefaction mixture of wood and starch. Mokuzai Gakkaishi 41:659-668

Yun JK, Yoo HJ, Kim HD (2007) Preparation and properties of waterborne polyurethane-urea/sodium alginate blends for high water vapor permeable coating materials. J Appl Polym Sci 105(3):1168-1176. https://doi.org/10.1002/app. 25731

Yuvarani I, Senthilkumar S, Venkatesan J, Kim SK, Al-Kheraif AA, Anil S, Sudha PN (2015) Chitosan modified alginatepolyurethane scaffold for skeletal muscle tissue engineering. J Biomater Tissue Eng 5(8):665-672. https://doi.org/ 10.1166/jbt.2015.1358

Zimmermann MVG, Turella TC, Santana RMC, Zattera AJ (2014) The influence of wood flour particle size and content on the rheological, physical, mechanical and morphological properties of EVA/wood cellular composites. Mater Des 57:660-666. https://doi.org/10.1016/j.matdes. 2014.01.010

Publisher's Note Springer Nature remains neutral with regard to jurisdictional claims in published maps and institutional affiliations. 